\title{
Sisäinen yrittäjyys \\ organisaation kehittämisen \\ välineenä
}

\author{
Jarna Heinonen
}

\begin{abstract}
Sisäisellä yrittäjyydellä haetaan tehokkuutta niin työyhteisön toimintaan, kuin sen jäsenten omaan kasvuun.

Sisäinen yrittäjyys ilmentää työyhteisön yrittäjämäistä ajattelu-, toiminta- ja suhtautumistapaa. Tässä artikkelissa tarkastellaan lähemmin kahta kunnallista yksikköä, hammashoitolaa ja vanhainkotia, jotka eroavat johtamisja toimintakulttuureissaan tuntuvasti toisistaan.
\end{abstract}

\begin{abstract}
Erityisesti 1980-luvulle tultaessa perinteinen yrittäjyyden käsite on laajentunut. Pienyrityksen omistajan ja johtajan rinnalle (ulkoinen yrittäjyys) on muotoutunut sisäisen yrittäjyyden käsite. (Kyrö 1997) Sisäisen yrittäjyyden käsitettä on syytä tarkastella yrittäjyys-käsitteen kehittymisen valossa, vaikka sisäistä yrittäjyyttä sellaisenaan ei varhaisesta yrittäjyyskirjallisuudesta löydy lähinnä organisaatioiden kehittymättömyydestä johtuen. Sisällöllisesti sisäinen yrittäjyys on kuitenkin ollut mukana yrittäjyyskirjallisuudessa sen alkuvaiheista lähtien.
\end{abstract}

Suomessa sisäinen yrittäjyys on ollut voimakkaasti esillä 1990-luvulla haettaessa lääkkeitä laman tuomiin vaikeuksiin. Samanaikaisesti sisäinen yrittäjyys on liitetty yhä voimakkaammin julkiseen sektoriin, jossa jäykähköt organisaatiorakenteet ja toimintatavat ovat tulleet uudelleen arvioinnin kohteiksi. On havaittu, että julkisen sektorin kilpailukykyä ja laatua ei enää nykyään, eikä varsinkaan tulevaisuudessa, voida ylläpitää lisääntyvin resurssein. Näin ollen sisäinen yrittäjyys innovatiivisine toimintatapoineen on liitetty julkisen sektorin muutosprosesseihin.
Sisäinen yrittäjyys on monitahoinen ilmiö, joka yleisessä kielenkäytössä on merkitykseltään laajentunut ja samalla hämärtynyt. Sisäisen yrittäjyyden tutkimus liittyy olennaisesti yrittäjyyden tutkimusparadigmaan ja tuo siihen uuden ulottuvuuden: yrittäjämäisen toimintatavan organisaation kehittämisen ja uudistumisen välineinä.

\section{Tarkoitus, menetelmät ja tutkimuskohde}

Tarkastelen tässä artikkelissa sisäisen yrittäjyyden käsitettä ja sisäisen yrittäjyyden edellytyksiä organisaatiossa, erityisesti kunnallisessa yksikössä. Päämäärään pyritään empirian ja teorian vuoropuhelulla, jossa kuvataan ja luodaan parempi ymmärrys kunnallisen yksikön sisäisestä yrittäjyydestä. Erityispiirteistään huolimatta kunnallinen yksikkö voidaan monelta osin nähdä yrityksen kaltaisena yksikkönä. Tarkastelun kohteena oleville case-yksiköille voidaan määritellä asiakas, markkinat, kilpailijat, tuote (tavara tai palvelu) sekä toiminnan tavoitteet. Näiden samankaltaisuuksien varaan perustuu tutkimuksen analoginen lähestymistapa, jossa liiketaloustieteen 
käsitteistöä hyödynnetään kunnallista yksikköä tutkittaessa.

Artikkeli perustuu pääsääntöisesti kahden kunnallisen yksikön - hammashoitolan ja vanhainkodin - toiminnan syvälliseen case-tarkasteluun (ks. Heinonen 1999b). Lisäksi empiriaa värittää työskentelyni erilaisissa tutkimus-, koulutus- ja kehittämishankkeissa tutkimuksen case-kunnissa, muissa kunnissa, julkisen sektorin organisaatioissa sekä yksityisen sektorin yrityksissä. Erityisesti artikkelin lopussa tutkimuksen johtopäätöksiä pohtiessani hyödynnän myös muista tutkimushankkeista saamiani tuloksia ja kokemuksia.

Tutkitun hammashoitolan toimintaa ovat 1990luvun alussa ohjanneet niukat resurssit sekä tiukka kunnallistaloudellinen tilanne. Hammashoitolan osapäiväinen vetäjä on yhteistyössä henkilökunnan kanssa pyrkinyt vastaamaan kunnan asettamiin tavoitteisiin: kohottamaan hammashoitolan imagoa ja saamaan aikaan säästöjä. Tavoitteiden saavuttaminen on edellyttänyt sitä, että maksavien asiakkaiden suhteellista osuutta on selkeästi kasvatettu. Käytännössä tämä on merkinnyt hammashoitolassa toiminta- ja organisointitapojen muutosta siten, että myös hammashoitajat ovat siirtyneet asiakastöihin (esimerkiksi lapsien ennaltaehkäisevä työ, yksilöllinen valistus, ravintoneuvonta), jolloin hammaslääkäreillä on vapautunut aikaa vaativampiin hoitotehtäviin.

Tutkittua vanhainkotia on kehitetty aktiivisesti 1980-luvun lopulta lähtien. Monia muutoksia on tehty. On toteutettu uusi osastojako (luotu aikaisempaa pienemmät osastot, joilla on kehittämisvastuu omasta työstään), on lisätty henkilöstöä ja kohotettu henkilöstön koulutus- ja vaatimustasoa, tehty muutoksia fyysisessä ympäristössä (pienimuotoisia parannuksia sekä merkittävä saneeraustyö), työskentelytapoja ja asenteita on muutettu (laajennettu työnkuvia ja lisätty vastuuta). On myös otettu paremmin huomioon asukkaiden yksilöllisyys (joustamalla päivärytmeissä). Ko. vanhainkoti on kunnallisessa ympäristössä sikäli harvinainen yksikkö, että kehitystyötä 1990-luvulla on voitu tehdä aikai- sempaa paremmin taloudellisin resurssein johtuen lähinnä ko. kunnan kasvukehityksestä ja siitä, että vanhainkoti oli alun perin käynnistetty hyvin vähäisin resurssein.

Tutkimushetkellä case-yksiköt olivat hyvin erilaisessa tilanteessa sisäisen yrittäjyyden toteutumisen näkökulmasta tarkasteltuna. Tutkimustuloksina esitetty analyysi luvussa neljä perustuu tutkittavista yksiköistä esiin nousseiden samankaltaisuuksien ja eroavaisuuksien varaan. Liiketaloustieteen käsitteistön soveltamisen kannalta on merkittävää, että kumpikin tarkasteltu yksikkö muodostaa selkeän ja rajattavissa olevan kokonaisuuden ja toiminnalle voidaan löytää markkinoilta vaihtoehtoisia ratkaisuja. Hammashoitoalalla toimii yksityisiä kilpailijoita, jotka täydentävät kunnallisesti tuotettuja suun ja hampaan terveydenhuollon palveluja. Vaikka julkinen sektori vastaa pääsääntöisesti vanhusten hoivatyöstä, markkinoilla on julkista kokonaistarjontaa täydentäviä ja kilpailevia yksityisiä vanhainkoteja.

\section{Sisäinen yrittäjyys käsitteenä}

Yrittäjyys tieteenalana on kehittynyt ilman yksiselitteistä teoreettista pohjaa tutkimuksen painopisteiden vaihdellessa tutkijasta ja ajankohdasta riippuen (Bygrave - Hofer 1991, ks. myös Steyaert 1995). Pitkälti ollaan yhtä mieltä siitä, että yrittäjyystutkimuksen huomion keskipisteenä on prosessi, jolla yksilö tai organisaatio luo ja toteuttaa uusia ideoita ja toimintatapoja, vastaa ennakoiden ympäristön haasteisiin sekä näin edistää epävarmojen ja monimutkaisten muutos- 


\section{A R T I K K E L I T}

ten toteutumista (Gibb 1999, Landström 1998). Akateemisessa yhteisössä sisäinen yrittäjyys nousi pinnalle vuonna 1990 Strategic Management Journalin julkaistessa erikoisnumeron ${ }^{1}$ sisäisestä yrittäjyydestä. Tätä ennen 1980-luvun alkupuolella mm. Burgelman (1983a, 1983b), Kanter (1983) ja Pinchot (1985) toivat sisäinen yrittäjyyden strategiakirjallisuuteen.

Sisäinen yrittäjyys perustuu schumpeterilaiselle käsitykselle yrittäjyydestä korostaen yrittäjyyden prosessia (entrepreneur carries out new combinations) ja innovatiivisuutta (Guth - Ginsberg 1990). Gifford Pinchot (1985) esitteli termin "intrapreneur" - sisäinen yrittäjä - erottaen toisistaan suuren organisaation sisäisen yrittäjän ja organisaation ulkopuolisen yrittäjän. Sisäinen yrittäjä toimii yrittäjän tavoin toteuttamalla omia ideoitaan olematta siltikään yrityksen omistaja (Cunningham - Lischeron 1991). Anttiroiko ja Tiura (1997) erottelevat yrittäjyyden työelämään liittyvään ulkoiseen ja sisäiseen yrittäjyyteen määrittelemällä sisäisen yrittäjyyden yrittäjämäiseksi käyttäytymiseksi toisen henkilön tai organisaation palveluksessa. Sisäinen yrittäjä on yrityksen sisäisen yrittäjyyden ydintoimija: organisaation palveluksessa oleva työntekijä, jonka työhön liittyvä itsensä toteuttaminen kanavoituu organisaation tavoitteiden ja toiminnan kautta. Sisäisen yrittäjyyden "luoja" Pinchot (1985) pitää sisäistä yrittäjää yrityksen palveluksessa olevana työntekijänä, joka toteuttaa unelmansa ("The Dreamers Who Do"). Sisäisen yrittäjyyden lähtökohtana on ajatus yrittäjyydestä inhimillisenä, luovana toimintana ja uuden luojana. Sisäinen yrittäjyys ei edellytä (taloudellisen) yrittäjäriskin olemassaoloa, joskin riskin ottaminen sinänsä liittyy sisäiseen yrittäjyyteen, sillä sisäinen yrittäjä on tunnistettavissa lähinnä vastuun kantamisen ja innovatiivisen työntekotavan perusteella (ks. Huuskonen 1992).

Tämän tutkimuksen kannalta hedelmällisen lähtökohdan tarjoaa muutostarpeen arvioinnista ja tilanteeseen sopeutumisesta kumpuava yrittäjyystutkimus. Cunningham ja Lischeron (1991) pitävätsisäisenyrittäjyydenkoulukunnanyrittäjyystutkimustatämän näkökulman edustajana. Sisäisen yrittäjyyden koulukunnan mukaan yrittäjämäinen toi- mintatapa voi olla hyödyllistä monimuotoisessa organisaatiossa, koska yrittäjyyden avulla organisaatiossa kehitetään itseohjautuvia yksiköitä, joiden tavoitteena on luoda, markkinoida ja laajentaa palveluita. Taustavaikuttimena on organisaation tarve muutokseen, jotta se säilyy hengissä. Yrittäjämäisen toimintatavan uskotaan koulukunnan perusoletusten mukaan johtavan organisaation uudelleen muotoutumiseen ja yrittäjämäiseen johtamiseen. Tarvetta tällaiseen mahdollisuuksien havaitsemiseen ja niihin tarttumiseen tähtäävään käyttäytymiseen on tyypillisesti kypsyys- ja muutosvaiheessa olevalla organisaatiolla (Cunningham - Lischeron 1991) - monet julkisen sektorin organisaatiot ovat juuri tällaisessa vaiheessa.

Tarkastelun kohteena tässä artikkelissa on kunnallisen yksikön sisäinen yrittäjyys, joka asettaa omat vaatimuksensa organisaatiolle ja sen johtamiselle. Sisäisellä yrittäjyydellä tarkoitetaan yrittäjämäistä toimintatapaa olemassa olevassa organisaatiossa. Sisäisen yrittäjyyden lähtökohta on mahdollisuuden olomassaolo ja sen havaitseminen, siihen tarttuminen sekä luottamus siihen, että mahdollisuuteen tarttuminen uudella, aikaisemmin totutusta poikkeavalla tavalla onnistuu ja tukee organisaation tavoitteiden toteutumista. Yrittäjämäinen toimintatapa on toimintaa, jonka avulla yksilö, ryhmä ja/tai kunnallinen yksikkö parantaa kykyään aikaansaada, kehittää ja selviytyä menestyksekkäästi muutoksista ja innovaatioista, joihin sisältyy hyvin paljon epävarmuutta ja monimutkaisia tilanteita sekä näin toimimalla saamaan henkilökohtaista tyydytystä. Lopulta määritellään vieläyrittäjämä̈isentoimintatavanjasisäisenyrittäjyydensuhde toisiinsa: yrittäjämäinen toimintatapa määrittää toimintatavan ja sen vaikuttimet - sisäinen yrittäjyys liittää toimintatavan olemassa olevaan organisaatioon ja sen tavoitteisiin. (Heinonen 1999b)

\section{Sisäisen yrittäjyyden edellytykset organisaatiossa}

Tarkastelen artikkelissani sisäistä yrittäjyyttä organisaatiotasolla, jolloin sisäisen yrittäjyyden elementit voidaan aikaisempaan kirjallisuuteen perustuen koota yhteen seuraavasti (ks. Guth - 


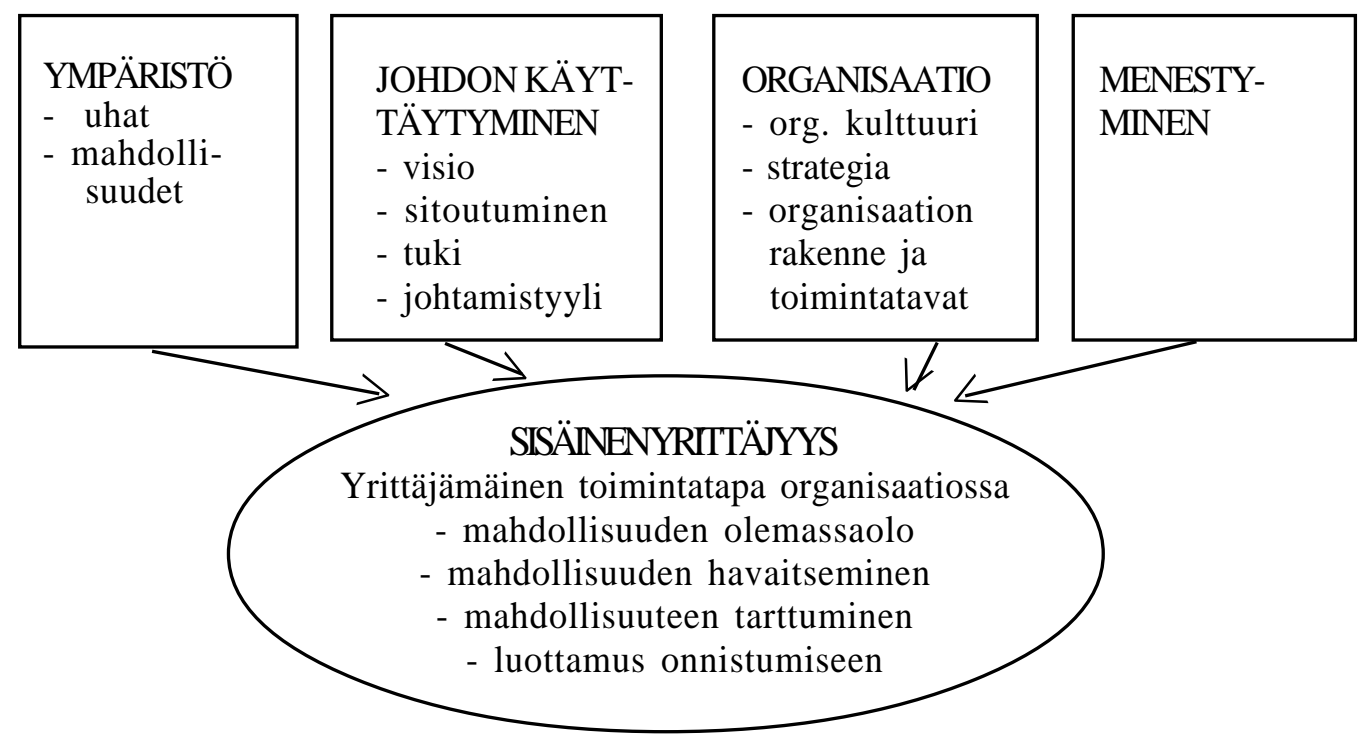

Kuvio 1. Sisäiseen yrittäjyyteen vaikuttavat tekijät (mukailtu lähteistä Guth - Ginsberg 1990, Miller 1983, Kuratko et al. 1990)

Ginsberg $1990^{2}$, Miller $1983^{3}$, Kuratko et al. $1990^{4}$ ). Tarkastelen kutakin elementtiä erikseen sekä teoriaan että empiriaan perustuen. Esitetty kuvio (Kuvio 1) ei ole suoranaisesti malli sisäisen yrittäjyyden elementeistä, vaan sen avulla pyrin jäsentämään aiheesta käytävää keskustelua. Olen päätynyt kuvioon yhdistämällä eri tutkijoiden käsityksiä sisäisen yrittäjyyden elementeistä. Seuraaviin lukuihin (4.1. - 4.4.) olen kerännyt keskeiset tulokset sisäisen yrittäjyyden edellytyksistä tutkituissa kunnallisissa organisaatioissa. Kunkin luvun alussa esitän ko. elementtien teoreettiset lähtökohdat aikaisempaan kirjallisuuteen perustuen. Tämän jälkeen esitetään ko. kunnallisten yksiköiden case-tutkimusten analyysien tulokset.

\section{Ymp ärist $\ddot{0}$}

Sisäinen yrittäjyys on prosessi, joka tapahtuu vuorovaikutuksessa ympäristön kanssa (ks. van de Ven 1993). Organisaation ulkoista toimintaympäristöä on vaikeaa kontrolloida, mutta sisäisesti yritteliäs organisaatio kykenee mukautumaan ympäristöön ja hyödyntämään sen mahdollisuudet (Guth - Ginsberg 1990). Ympäristö tarjoaa organisaatiolle mahdollisuuksia ja luo organisaatiolle uhkia (MacMillan 1986, Guth - Ginsberg
1990). Ympäristöä seuraamalla voidaan saada selville muutokset ja muutossuunnat sekä tulkita näitä suhteessa organisaatioon ja sen toimintaresursseihin (Ansoff 1981). Millerin (1983) mukaan suunnittelupainotteisissa organisaatioissa, jollaisia tutkitut kunnalliset yksiköt ovat, ympäristön vaikutus yrittäjämäiseen toimintaan, innovatiivisuuteen ja muutokseen on olematon, sillä yrittäjämäinen toiminta riippuu organisaation sisäisestä aloitteesta.

Case-yksiköistä kerätyn empirian perusteella yksikön toimintaan vaikuttavana ulkopuolisena tekijänä pidetään budjettia eli toimintaan allokoituja rahallisia resursseja, jotka määritellään poliittisen päätöksentekoprosessin tuloksena kunnallisessa demokratiassa. Kilpailijoiden ei nähdä konkreettisesti vaikuttavan yksikön toimintaan, vaikka kilpailutilanne jossakin määrin toimii kehittämisen katalysaattorina. Kunnallistalouden yleinen tilanne, työttömyys ja lakimuutokset aiheuttavat kunnallisille yksiköille paineita. Palvelutarve kasvaa, mutta samanaikaisesti resurssit käyvät niukemmiksi. Tämän vuoksi taloudellinen motiivi on usein keskeinen muutoksiin ja kehittämistyöhön ryhdyttäessä. Hammashoitolassa toimintaympäristön dynamiikka ja ympäristöstä nousevat haasteet eivät ole kannustaneet sisäi- 
seen yrittäjyyteen - paremminkin päinvastoin. Toimintaympäristön muutokset ovat luoneet työntekijöissä epävarmuuden ja turvattomuuden tunteen, mikä on vähentänyt sitoutumista organisaatioon ja kehittämistoimintaan. Vanhainkodissa toimintaympäristön vaikutusta ei ole koettu negatiivisesti esteenä, vaan kasvaneista resursseista johtuen positiivisena mahdollisuutena, mikä on kannustanut yksikköä lunastamaan sille asetetut odotukset - ts. kannustanut yksikköä aktiiviseen kehittämistoimintaan.

Empirian perusteella keskeisiksi nousevat johdon tulkinta toimintaympäristön muutoksista - onko kyse uhasta vai mahdollisuudesta - sekä yksikön käytössä olevat resurssit vastata toimintaympäristön muutoksiin. Näin ollen tutkimustulokset saavat tukea siitä Millerin (1983) näkemyksestä, että suunnittelupainotteisessa organisaatiossa sisäinen yrittäjyys riippuu organisaation sisäisestä aloitteesta, ei niinkään toimintaympäristöstä.

\section{Johdon käyttäytyminen}

Organisaation ylimmän johdon tehtävä on tulkita ympäristön mukanaan tuomia muutossuuntia sekä arvioida muutosten vaikutuksia organisaatioon. Monimutkaiseen arviointiin vaikuttavat sekä objektiiviset että subjektiiviset tekijät, joiden pohjalta johto muodostaa käsityksensä organisaation kyvystä vastata muutoksiin. (Ansoff 1981) Ansoffin mukaan organisaation johdon vastuulle kuuluu varmistaa organisaation onnistumisen ja hengissäpysymisen takaava strateginen käyttäytyminen. Sisäinen yrittäjyys keinona hallita organisaation muutosta lähtee liikkeelle organisaation ylimmästä johdosta. Ylimmän johdon lisäksi keskijohdon toiminta erilaisissa vuorovaikutussuhteissa heijastuu sisäiseen yrittäjyyteen (Koiranen - Pohjansaari 1994).

Case-yksiköiden vetäjiä voidaan kuvata suorasanaisiksi ja avoimiksi henkilöiksi, joten edellytykset avoimeen ja joustavaan johtamistyyliin ovat olemassa. Vanhainkodin vetäjä pyrkii innostamaan ja kannustamaan työntekijöitä kehittämään toimintaa ja kokeilemaan uutta, mihin hän myös antaa vapauden. "Ylivalmentaja" ja "primus motor" ovat ilmaisuja, jotka kuvaavat vetäjän roo- lia. Hammashoitolassa asioista ei työyhteisössä yhdessä aktiivisesti keskustella, vaan informointi tapahtuu tiedotusluontoisesti, jolloin johtopäätösten teko jää työntekijöille itselleen. Yksikön vetäjää pidetään jossakin määrin autoritäärisenä johtajana, ei niinkään ryhmän valmentajana ja sitouttajana. Työntekijäpuolella johdon kyky tai halu tarttua uudistusehdotuksiin koetaan rajallisina, mikä ainakin jossakin määrin on latistanut henkilökunnan kehittämisinnokkuutta. Tämä johtunee osaltaan johtamiseen allokoiduista vähäisistä aikaresursseista sekä yksikön sisäisistä kommunikointivaikeuksista.

Edelliseen perustuen, jos ajatellaan sisäisen yrittäjyyden toteutumista, johdon käyttäytymisessä keskeisessä asemassa on johdon konkreettinen osallistuminen yksikön päivittäiseen toimintaan. Mitä kiinteämmin yksikön johto johtajana työskentelee yksikön muiden työntekijöiden kanssa, sitä paremmat edellytykset hänellä on edistää sisäistä yrittäjyyttä. Osallistumiseen liittyen merkitystä on myös sillä, miten yksikön johtaminen on resursoitu ja organisoitu, koska johtaminen esimerkiksi oman toimen ohella ei anna johtajalle mahdollisuutta panostaa toimintaan riittävästi. Julkisen sektorin johtamisen haasteellisuutta lisää toimintaympäristöstä nousevien kehittämispaineiden vähäisyys, jolloin johdon on omalla toiminnallaan löydettävä kannusteet ja motivaatio kehittämiseen yksikön sisältä. (Ks. julkisen johtamisen haasteista ja arvostuksesta Heinonen 1999a.) Perinteinen kunnallinen duaaliorganisaatio, jossa luottamushenkilö- ja virkamiesorganisaatio toimivat rinnakkain, ei ole omiaan kannustamaan yksikön johtoa muutoksiin ja ottamaan niiden edellyttämää riskiä.

”...Että jos saisi virkamiehen kiinni jostakin virheestä...Että kerta kaikkiaan vahdittiin, ettet vaan ole mitään päätöstä väärin noudattanut...Niin ei tämä mihinkään riskien ottamiseen totisestikaan kannusta..."

\section{Organisaatiorakenne ja toimintatavat}

Sisäisen yrittäjyyden organisatorisina edellytyk- 
sinä kirjallisuudesta nousevat esiin organisaatiokulttuuri, strategia sekä organisaatiorakenne ja toimintatavat (Guth - Ginsberg 1990). Seuraavassa kutakin näistä käsitellään erikseen, vaikka ne vaikuttavat toisiinsa.

\section{Organisaatiokulttuuri}

Organisaatiokulttuuri vaikuttaa sisäiseen yrittäjyyteen luoden sille kasvualustan (MacMillan 1986). Organisaatiokulttuuri käsitteenä ei ole yksiselitteinen, ja sen sisältö vaihtelee näkökulmasta riippuen (Alvesson 1993). Akateemisessa kirjallisuudessa ollaan yhtä mieltä seuraavista organisaatiokulttuuriin liittyvistä asioista (Wilson 1997):

Organisaatiokulttuuri on näkyvät ja vähemmän näkyvät, työntekijöiden ryhmälle yhteiset normit, arvot ja käyttäytyminen, jotka muovaavat ryhmän käsitystä siitä, mikä on hyväksyttävää ja tarkoituksenmukaista. Normit, arvot ja käyttäytyminen muuttuvat yleensä hitaasti, ja uusi työntekijä oppii ne muodollisessa ja epämuodollisessa sosiaalisessa prosessissa.

Case-yksiköiden organisaatiokulttuurista löytyy selkeitä eroavaisuuksia. Hammashoitolan organisaatiokulttuurissa on havaittavissa pelon ja epävarmuuden tunne ja ilmapiiri, jotka perustuvat ko. kunnassa, erityisesti sosiaali- ja terveystoimessa 1990-luvun puolivälissä toteutettuihin muutoksiin, irtisanomisiin ja lomautuksiin. Riippumatta siitä, kuinka tietoisesti pelon tunnetta käytetään johtamiskeinona, tunnetasolla epävarmuus vaikuttaa työntekijöiden sitoutumiseen ja kehittämisintoon. Käyttäytymistä hammashoitolassa määrittävät erilaiset, yhteisen kanssakäymisen tuloksena syntyneet pelisäännöt, jotka eivät jätä työntekijän yksilöllisyydelle kovin paljoa tilaa. Vanhainkodissa puolestaan yksilöllisyys organisaation arvona korostuu - niin suhteessa asiakkaaseen kuin työntekijäänkin. Työntekijöiden sisäisen yrittäjyyden nähdään liittyvän yksilön perusasennoitumiseen.

”...Minun mielestäni julkisen hallinnon alalla just ihmiset tekevät itsellensä karhunpalveluksen semmosella asenteella, että mä oon täällä vaan töissä... Että voithan sä marmattaa ja valittaa ja antaa asian olla. Mutta jos sä näet jonkun epäkohdan, niin sinulla on oikeus ja velvollisuus tarttua siihen ja tehdä sille jotain. Tämä on se peruskulttuurikysymys ehkä."

Tutkimuksen empirian perusteella organisaatiokulttuurin perusoletuksena turvallisuus ja luottamus luovat sisäiselle yrittäjyydelle suotuisan kasvualustan. Kun kunta kohdistaa kunnallisen yksikön toimintaan suuria muutospaineita tai tiukkoja tavoitteita, mitataan yksikön johdon kykyä toimia puskurina kunnan ja yksikön henkilökunnan välissä. Kun työyhteisössä voidaan luottaa siihen, että organisaation peruslähtökohdat on turvattu, työntekijöiden sitoutuminen yhteisön ja itsensä kehittämiseen paranee. Yhteisen tavoitteen ja kunnianhimoisen tavoitteellisuuden rakentaminen ja työstäminen luottamuksen ilmapiirissä siten, että jokainen työntekijä ymmärtää oman roolinsa kokonaisuudessa, lisää sisäisen yrittäjyyden edellytyksiä. Lopulta organisaatiokulttuuri määrittää sen, kuinka yhteisössä hyväksytään yksilöllisyys - niin työyhteisön sisällä kuin suhteessa asiakkaaseen. Tutkimukseni (1999b) perusteella tasa-arvoa ja ääretöntä konsensusta korostava organisaatiokulttuuri ei salli yksilöllisyyttä eikä näin kannusta sisäiseen yrittäjyyteen.

\section{Strategia}

Strategiassa määritellään lähinnä organisaation suhde ympäristöönsä. Strategia ohjaa organisaation toimintaa, sillä yleensä strategia sisältää organisaation toimialueen (markkinat), keskeiset kilpailutekijät, joiden varaan organisaation menestys rakentuu, sekä tavoitteet, joihin organisaatio pyrkii. (Day 1990) Strategisessa johtamisessa on kyse siitä, että organisaation toiminta saatetaan samalle aaltopituudelle ympäristön tarjoamien mahdollisuuksien ja uhkien kanssa (Ansoff 1981).

Case-yksiköiden strategiset lähestymistavat muistuttavat toisiaan siinä mielessä, että lähtökohdat strategioihin löytyvät ko. kunnasta. Vanhainkodin strategia rakentuu kunnan vanhustenhuollon strategiaan, jossa pyrkimyksenä on pitää vanhus avohuollon keinoin kotona niin pitkään kuin mahdollista. Hammashoitolan toimintaa 
ohjaavat kunnalta annetut tiukat taloudelliset raamit. Molemmissa yksiköissä toimintaa ohjaa lisäksi pyrkimys kohtuulaatuiseen palvelutuotantoon, sillä julkisen sektorin resurssien sopivana käyttönä ei pidetä "ylipalvelun" antamista.

Tutkittujen yksiköiden strategiat ovat toiminnan ohjauksen tarpeita ajatellen puutteelliset ja hahmottumattomat. Yksiköiden strategiat ovat muodostuneet pitkälti kuntien tahdonilmaisuna, jota yksiköissä kykyjen ja resurssien puitteissa pyritään toteuttamaan. Yksikön oma strategiatyö kunnalta yksikölle asetetun strategian kehittämiseksi on lähes olematonta, mistä johtuen strategiat ovat hyvin yleisellä tasolla. Strategian täsmentymättömyyteen vaikuttaa se, että asiakasvirta koetaan ehtymättömäksi.

\section{Organisaatiorakenne ja toimintatavat}

Organisaatiorakenne ja strategia liittyvät toisiinsa sekä sisäiseen yrittäjyyteen (ks. Burgelman 1983a). Samalla tavoin kuin näkymätön osa organisaatiokulttuuria arvoineen ja uskomuksineen vaikuttaa organisaation sisäiseen yrittäjyyteen, organisaatiorakenne ja sen toimintatavat näkyvinä osina ovat sisäisen yrittäjyyden organisatorisia edellytyksiä (ks. Zahra 1991). Organisaatiorakenteet luovat puitteet: ne mahdollistavat ja samalla rajaavat organisaatiossa työskentelevien toimintaa (Heikkilä-Laakso - Heikkilä 1997).

Organisaatiorakenteen ja toimintatapojen suhteen case-yksiköt poikkeavat toisistaan, vaikka yksiköitä yhdistääkin sairaalamainen organisaatiorakenne. Hammashoitolassa odotetaan, että esimies kertoo, kuinka uusissa ja erilaisissa tilanteissa toimitaan. Yksikössä ei toimita kovin itsenäisesti ja itseohjautuvasti, vaikka johdon pyrkimyksenä on ohjata toimintaa siihen suuntaan. Vanhainkodissa itseohjautuvuuden merkitys huomattiin 1980-luvun lopussa pilkottaessa suuria osastoja pienemmiksi, jolloin ryhmän osaaminen ja resurssit kyettiin valjastamaan osastokohtaisten ongelmien ratkaisuun ja toiminnan kehittämiseen. Osastojen pienennyttyä vanhainkodista poistettiin perinteinen organisaatiorakenne hallinnollisine osastonhoitajineen ja erillisine sairaalaosastoineen. Myös kannustamisessa on havaittavissa eroavaisuuksia, joskin kummas- sakin yksikössä työ sinänsä ja sen sisältö nähdään jossakin määrin palkitsevana. Hammashoitolassa kaikki haastatellut kaipaavat konkreettisia, erityisesti rahallisia palkitsemis- ja kannustuskeinoja kunnalliseen toimintaan. Vanhainkodissa puolestaan vastuun antaminen ja saaminen, työn sisällön kehittäminen ja itsenäisyys nähdään selkeämmin myös työntekijöiden palkitsemis- ja kannustuskeinona.

Hammashoitolan toimintatapaa voidaan luonnehtia kohtuullisen perinteiseksi hoitajien toimintatavan muutoksesta huolimatta. Sairaalamaisuus tehtäväsidonnaisuuksineen vähäisiin kannuste- ja kommunikointijärjestelmiin ja heikohkoon työilmapiiriin yhdistettynä antavat yksikön toiminnalle perinteisen leiman. Vanhainkodin toiminnassa on nähtävissä edistyksellisen toimintatavan piirteitä, vaikka näiden ilmeneminen lienee hyvin osastokohtaista. Osastojen pienentäminen, toimintavapauksien lisääminen osastoilla, osastojen tiimiytyminen sekä koko yksikön yhteistyön kehittäminen ovat merkkejä edistyksellisyydestä.

Tutkittujen yksiköiden perusteella työntekijöiden päivittäisten työtehtävien parissa tehtävä luonnollinen yhteistyö yhteiseksi koetun tavoitteen saavuttamiseksi parantaa sisäisen yrittäjyyden toteutumisedellytyksiä. Joustavuus ja löyhät tehtäväkuvat mahdollistavat päivittäisen yhteistyön, kun puolestaan vallan ja vastuun epätasapaino sekä sääntöihin tukeutuminen saattavat tuottaa ongelmia. Kehittäminen ja muutos ovat investointeja tulevaisuuteen, minkä vuoksi kehittämistyöhön varattu aika edistää sisäistä yrittäjyyttä. Keskeiseksi nousee myös se, kuinka sisäistä yrittäjyyttä kannustetaan.

\section{Menestyminen}

Organisaation menestyminen ja sisäinen yrittäjyys liittyvät toisiinsa (Guth - Ginsberg 1990). Tutkimusten mukaan sisäinen yrittäjyys ensinnäkin parantaa organisaation (sekä taloudellista että ei-taloudellista) suorituskykyä (Pearce et al. 1997). Tutkimusten mukaan sisäisen yrittäjyyden ja menestymisen suhde on myös toisensuuntainen: organisaation menestyminen vaikuttaa 
sisäiseen yrittäjyyteen. Menestyvän organisaation on helpompi tarttua mahdollisuuksiin - innovoida ja muuttua - kun sillä on tarvittavat resurssit käytössään. (Guth - Ginsberg 1990).

Tutkimuksessani empirian perusteella yksikön sisäisen yrittäjyyden ja menestymisen välisen suhteen määrittely on monitahoista. Tulkintaan vaikuttaa toisaalta se, kuinka sisäinen yrittäjyys käsitteenä organisaatiossa ymmärretään ja toisaalta se, miten menestymistä arvioidaan. Kun sisäinen yrittäjyys hammashoitolan tapauksessa ymmärretään yritysmäiseksi tulosvastuuksi, menestystä arvioitaessa huomio näyttää keskittyvän toiminnan taloudellisiin argumentteihin ja asiakaspalautteeseen. Budjetissa pysyminen ja toiminnan taloudellisuus nähdään sisäisen yrittäjyyden osoituksina.

"...Mä luulen, että ne tekee niin paljon töitä, kun ne pystyy, että siellä siis kaikki ajat ovat varattuja. Mä en oikein tiedä, millä tavalla siellä pystyy sen yksikön sisällä enempää yritteliäisyyttä käyttämään...Minun mielestä se yksikkö tekee nimittäin niin tehokkaasti työtä kun kohtuudella voidaan vaatia."

Kun sisäinen yrittäjyys vanhainkodin tapauksessa nähdään yritysmäisyyttä selkeästi laajemmin yrittäjämäisenä ja itseohjautuvana toimintatapana sekä työyhteisön kehittämisenä, sisäisen yrittäjyyden taloudelliset tulokset koetaan vähäisiksi, sillä onnistumista mitataan lähinnä työyhteisön toimivuudella ja asiakaspalautteella. Osaksi sisäistä yrittäjyyttä nähdään myös tiimityöskentely ja tiimin tuki sekä työntekijän henkinen tyydytys.

"...Onhan se nyt paljon haastavampaa tehdä sillai. Että jos minäkin nyt vain päättäisin, että joo, minä saan sen tietyn summan rahaa joka kuukausi, kävelen tänne, palaan kotiin. Olisihan minun elämä tosi yksioikoista."

Organisaation menestyksen ja ennen kaikkea resurssien vaikutus sisäiseen yrittäjyyteen näyttäytyy tutkituissa yksiköissä samansuuntaisena. Riittävät resurssit ja menestyminen edistävät sisäistä yrittäjyyttä - vastaavasti vähäiset resurssit ja ne- gatiivinen arvostus vähentävät sitä. Vanhainkodissa aikaan saatu positiivinen kehä, jossa resurssien mukanaan tuoma arvostus on lisännyt yrittämisen halua, ruokkii sisäistä yrittäjyyttä. Sisäiseen yrittäjyyteen ei liity negatiivisia väritteitä: irtisanomisia, lomautuksia ja pakkosäästämistä. Työn kehittämiseen ja muutokseen voidaan investoida aikaa ja rahaa. Hammashoitolassa puolestaan epävarmuus tulevaisuudesta on luonut turvattoman ilmapiirin, jota niukat rahalliset resurssit ja jatkuvat säästötavoitteet lisäävät. Välttämättömiksi koettuihin uudistushankkeisiin ei ole kyetty investoimaan, mikä on laimentanut kehittämishalun entisestään. Negatiivista kehää täydentää voimakas julkisuuskeskustelu, jossa kehittämishankkeita ruoditaan puolin ja toisin.

\section{Sisäisen yrittäjyyden erityiset haasteet kuntasektorilla}

Sisäinen yrittäjyys käsitteenä on erityisen hahmottumaton kuntasektorilla. Tutkimuksessa kolme esiin tullutta sisäisen yrittäjyyden tulkintatapaa - yritysmäinen tulkinta, hallinnon tehokkuutta ja tulosvastuuta tavoitteleva tulkinta sekä itseohjautuvuutta, sitoutuneisuutta ja muutosta korostava tulkinta - vaikuttavat sisäisen yrittäjyyden toteuttamiseen. Varsinkin toiminnan yksityistämiseen liitettävä yritysmäinen tulkinta antaa sisäiselle yrittäjyydelle kuntasektorilla usein varsin negatiivisen sävyn.

Kunnallisen yksikön sisäistä yrittäjyyttä vaikeuttavat myös julkisen sektorin menettelytavat ja niiden konkretisoituminen kunnallisen yksikön toiminnassa. Nykyinen tilinpito-ja budjettijärjestelmä ei taloudellisesti kannusta sisäiseen yrittäjyyteen, koska yksikön tasolla saavutettu tulos useimmiten siirtyy kunnan heikoimmin menestyneiden yksiköiden rahoitusvajeen katteeksi.

"...Jos sä teet kauheasti [työtä], etkä sä saa siitä mitään hyötyä, niin minkä ihmeen takia?"

Julkisen sektorin menettelytavat sisäisen yrittäjyyden esteenä konkretisoituvat myös kunnallisen yksikönjohdon puutteellisina toimintavaltuuksina. Esimerkiksi henkilökunnan irtisanomissuoja 
ei mahdollista työyhteisöön sopimattoman tai peräti ammattitaidottoman henkilön irtisanomista vaikeuttaen johdon toimintaa sisäisen yrittäjyyden edistämisessä.

Poliittinen intressi on kunnallisen yksikön toiminnassa sisäisestä yrittäjyydestä irrallinen ilmiö, mikä kuitenkin vaikuttaa sisäisen yrittäjyyden toteutumiseen. Kunnallista toimintaa liiketaloustieteen käsitteisiin perustuen ei voi tarkastella ymmärtämättä politiikan mukanaan tuomia ohjausvaikutuksia. Toisaalta kunnallisen yksikön toiminta ei kehity yksipuolisesti poliittisen intressin ohjaamana. Politiikka tuo kunnallisen yksikön toiminnan kehittämiseen omat erityispiirteensä, mikä edustuksellisessa demokratiassa lähtökohtaisesti ei voi (toistuvasti) olla ristiriidassa kunnallisen yksikön menestymisen ja sisäisen yrittäjyyden toteuttamisen kanssa. Julkisen sektorin menettelytapojen näkyminen kunnallisen yksikön toiminnassa ajoittain hyvin voimakkaana herättää kysymyksen poliittisten päättäjien todellisesta tahtotilastaja rohkeudesta edistääsisäiseen yrittäjyyteen sisältyvää muutosta. Tutkimuksessani tarkastelin kuntatasolla vaikuttavien poliittisten päättäjien toimintaa. Mainitsemani tahtotila ja rohkeus liittyvät yhtä lailla valtakunnallisiin poliittisiin päättäjiin, sillä kyse on paitsi kuntatason päätöksistä, myös lainsäädännöllisistä asioista. Kuntalaki mahdollistaa esimerkiksi sen, että valtuusto voi päättää kunnallisen yksikön tuloksen tai katteen käyttämisestä ko. yksikön toimintaa kehittävästi. Käytännön sovellukset Suomessa ovat vähäisiä antaen viitteitä siitä, että päätöksentekijät kunnanvaltuustoissa tavoittelevat sisäisen yrittäjyyden mukanaan tuomia (taloudellisia) etuja, mutta eivät itse päätöksiä tehdessään ole halukkaita ottamaan sisäisen yrittäjyyden mahdollistamiseksi tarvittavia riskejä.

Case-yksiköiden tutkimustulosten pohjalta näyttää siltä, että ristiriitatilanteessa ainakin lyhyellä aikavälillä politiikka voittaa, ja kunnallisen yksikön sisäinen yrittäjyys juhlapuheista huolimatta jää käytännön työssä taka-alalle. Politiikkaa ei voi sulkea kunnallisen yksikön toiminnasta, vaan toiminnan kestävä kehittäminen rakentuu kunnallisen organisaation duaalisen luonteen ymmärtämiselle (ks. Möttönen 1998).

\section{Mutoksen aikaansaaminen}

Yksityisen sektorin yrityksistä saamieni kokemusten perusteella näyttäisi siltä, että sisäisen yrittäjyyden elementit voidaan jäsentää esitetyssä viitekehyksessä. Selkeinä poikkeuksina näyttäytyvät luonnollisesti julkisen sektorin erityispiirteet sekä yksityisellä sektorilla voimakkaammin koettava ulkoisen ympäristön muutospaine. Organisaatiotasolla sisäisen yrittäjyyden edellytykset muistuttavat kuitenkin pitkälti toisiaan korostaen johdon toiminnan merkitystä luotaessa organisaatiokulttuuria, strategioita, organisaatiorakenteita ja -toimintatapoja.

\section{Ylin johto luo perustan}

Organisaation ylimmän johdon tahtotila ja rohkeus sisäisen yrittäjyyden sisältämän muutoksen edistämisessä on tutkimusteni mukaan keskeinen sisäisen yrittäjyyden edellytys. Ylin johto on muutoksen ja sisäisen yrittäjyyden mahdollistaja. Organisaatiota voidaan kehittää sisäisen yrittäjyyden keinoin hyödyntämällä ympäristön muutokset ja ottamalla tuntematon tulevaisuus mahdollisuutena ja muuttamalla aikaisempia toimintatapoja radikaalisti. Sisäinen yrittäjyys tarvitsee toteutuakseen liikkumavaraa ja resursseja. Mikäli muutoksen käynnistämistä on pitkitetty, nämä resurssit on saatettu esimerkiksi vuosittaisten säästötoimenpiteiden johdosta karsia olemattomiksi. Tällöin vaarana on, että sisäiselle yrittäjyydelle ei löydy riittävää kasvualustaa ja organisaatio kehittyy negatiiviseen suuntaan. Erityisesti tällaisessa tilanteessa sisäisen yrittäjyyden kannustaminen edellyttää organisaation ylimmältä johdolta näkemystä tulevaisuudesta, riskinottokykyä ja taloudellista investointia tulevaisuuteen.

Ylimmän johdon tahtotilaan liittyy läheisesti myös johdon omat ja alaisilleen myöntämät toimintavaltuudet. Kasvualustan lisäksi sisäinen yrittäjyys ja muutoksen aikaansaaminen edellyttävät asianosaisilta riittäviä toimintavaltuuksia esimerkiksi kannusteiden määrittämisessä, henkilökunnan valinnassa ja töiden organisoinnissa.

\section{Tiukasti määritellyt visiot, arvot ja strategia ohjaavat}

Sisäisesti yritteliäässä organisaatiossa edistetään 
sisäiseen yrittäjyyteen liitettäviä arvoja: riskinottoa, vapautta ja yksilöllisyyttä. Kehitettäessä organisaatiota sisäisen yrittäjyyden keinoin organisaatiossa vähitellen luovutaan sisäisen yrittäjyyden periaatteiden mukaisesti muodollisista määräyksistä, ohjeista ja käskyistä organisaation keskeisinä ohjauskeinoina. Tällainen toimintaperiaatteisiin liittyvä "löyhyys" vaatii vastapainokseen tiukkuuttaorganisaation peruslähtökohdissa - visioissa, arvoissa, strategiassa - jotta organisaatio ei ohjaamattomana ajaudu kaaoksen kaltaiseen tilanteeseen. Muutostilanteessa johdon rooli organisaation vision, arvojen ja strategian muodostamisessa ja viestinnässä on oleellinen. Vasta organisaation kaikilla tasoilla sisäistettynä organisaation visio, arvot ja strategia ohjaavat käytännön toimintaa. Johdon roolia sisäisen yrittäjyyden edistäjänä korostaa myös se, että kehittämistyö käynnistyy usein johdon aloitteesta. Johto vaikuttaa omalla toiminnallaan siihen, miten yksikön visio, arvot ja strategia muodostuvat, sekä siihen, miten niitä levitetään ja toteutetaan.

\section{Sanahelinästä käytäntöön}

Organisaatiossa määriteltyjen visioiden, arvojen ja strategioiden toteuttaminen käytännössä on pitkälti kiinni siitä, kuinka sanat muuttuvat teoiksi ja luonnolliseksi osaksi jokaisen työntekijän työtä. Johdon toimiessa muutoksen ja sisäisen yrittäjyyden mahdollistajana työntekijä - sisäinen yrittäjä -tarttuu tähän mahdollisuuteen. Näin toteutuu yrittäjyyden oleellinen prosessi: havaita mahdollisuus ja tarttua siihen. On ensiarvoisen tärkeää saada koko henkilökunta yhteisvoimin mukaan organisaation kehittämistyöhön aina vision, arvojen ja strategioiden määrittelystä lähtien. Sisäisenä yrittäjänä toimiminen edellyttää sitä, että työntekijä ymmärtää oman työpanoksensa merkityksen organisaatiossa. Toiminnan ohjausta silmällä pitäen yhteisesti määriteltyjen visioiden, arvojen ja strategioiden on konkretisoiduttava jokaisen työntekijän työssä: kuinka ne näkyvät minun työssäni, kuinka ne muuntuvat oleelliseksi osaksi työtäni ja kuinka ne ohjaavat päivittäistä työskentelyäni? Yhteiset palaverit, työn arviointi, kehitys- ja palautekeskustelut ja kehittämishankkeet ovat konkreettisia keinoja yhteisen kielen ja toimintaperiaatteiden välittämiseen. Organisaation muutosprosessi sisäistä yrittäjyyttä hyödyntäen on osaltaan myös johdonmukaista sisäisen yrittäjyyden arvoja korostavaa symboliikkaa ja semantiikkaa, jossa organisaation johdon on kerta toisensa jälkeen toistettava ja tehtävä näkyväksi organisaation perusperiaatteita, vaikka ne johdon näkökulmasta saattavat vaikuttaa jo vähintäänkin itsestään selvyyksiltä.

\section{Suuntaa jatkotutkimukselle}

Empiirinen case-aineistoni keskittyy kunnallisiin yksikköihin. Sisäinen yrittäjyys monitahoisena ilmiönä on kuitenkin sovellettavissa hyvin erilaisiin organisaatioihin. On oletettavaa, että erilaisissa organisaatioissa eri tekijät painottuvat sisäisen yrittäjyyden edellytyksinä. Olisikin tarkoituksenmukaista tarkastella sisäisen yrittäjyyden edellytyksiä erilaisissa organisaatioissa.

Sisäisellä yrittäjyydellä on vaikutusta organisaation menestymiseen. Sisäisen yrittäjyyden ja organisaation menestyksen välistä suhdetta erilaisissa organisaatioissa ei toistaiseksi ole kuitenkaan tutkittu riittävästi. Tämän tutkimuksellinen kapeikon analysointi ja arviointi olisi luonnollinen jatke omalle tutkimukselleni.

Käyttämäni viitekehys sisäisen yrittäjyyden elementeistä mahdollistaa kehitettynä ja operationalisoituna sen, että organisaation sisäisen yrittäjyyden tasoa voidaan mitata. Tällaisen mittariston laatiminen antaa pohjaa myös laajemman ilmiötä käsittelevän empiirisen aineiston keruulle erilaisissa organisaatioissa ja mahdollistaa monia mielenkiintoisia tutkimusasetelmia niin yksilön, yksittäisen organisaation kuin useampien organisaatioidenkin tasoilla: Voidaan arvioida yksittäisen työntekijän valmiuksia toimia sisäisenä yrittäjänä ja tunnistaa yksilön henkilökohtaisia kehittämisalueita. Tuloksia voidaan hyödyntää organisaatiossa sisäisen yrittäjyyden kehittämishankkeissa. Voidaan myös arvioida erilaisten organisaatioiden valmiuksia sisäiseen yrittäjyyteen sekä löytää erityyppisiä organisaatioita ja näille soveltuvia kehittämiskeinoja. 


\section{Lähteet}

ALVESSON, Mats (1993) Cultural Perspectives on Organizations. Cambridge University Press: Cambridge.

ANSOFF, Igor H. (1981) Strateginen johtaminen. Ekonomia-sarja. Weilin+Göös: Espoo.

ANTTIROIKO, Ari-Veikko - Tiura, Marja (1997) Sisäinen yrittäjyys julkisissa organisaatioissa. Sisäinen yrittäjyys julkisen hallinnon tehokkuuden ja vaikuttavuuden parantamisen keinona. Tampereen yliopisto. Kunnallistieteiden laitos. Raporttisarja 35/1997. Tampere.

BURGELMAN, Robert A. (1983a) A Model of the Interaction of Strategic Behavior, Corporate Context, and the Concept of Strategy. Academy of Management Review, Vol. 8, No. 1, 61-70.

BURGELMAN, Robert A. (1983b) Corporate Entrepreneurship and Strategic Management: Insights from a Process Study. Management Science, Vol. 29, No. 12, 1349-1364.

BYGRAVE, William D. - Hofer, Charles W. (1991) Theorizing about Entrepreneurship. Entrepreneurship Theory and Practice, Vol. 15, Winter 1991, 1322.

CUNNINGHAM, J. Barton - Lischeron, Joe (1991) Defining Entrepreneurship. Journal of Small Business Management, Vol. 29, No. 1, 45-61.

DAY, George S. (1990) Market Driven Strategy. Process for Creating Value. The Free Press: New York.

GIBB, Allan (1999) The Future of Work and the Role of Entrepreneurship and Enterprise Education in Schools and Further Education. Keynote to $3^{\text {rd }}$ Finnish SME Forum, February $3^{\text {rd }} 1999$. Turku.

GUTH, William D. - Ginsberg, Ari (1990) Guest Editors' Introduction: Corporate Entrepreneurship. Strategic Management Journal, Vol. 11, Summer Special Issue, 5-15.

HEIKKILÄ-LAAKSO, Kristiina - Heikkilä, Jorma (1997) Innovativisuutta etsimässä. Irtiottoa keskinkertaisuudesta. Turun opettajainkoulutuslaitos. Julkaisusarja B Selosteita. Turun yliopiston kasvatustieteiden tiedekunta: 57.

HEINONEN, Jarna (1999a) Epilogi. Teoksessa Julkisten palvelujen laatu ja kilpailukyky (Mäki, Katja - Sorri, Taija). Valtiovarainministeriön hallinnon kehittämisosaston tutkimukset ja selvitykset 2/ 1999. Helsinki, 180-181.

HEINONEN, Jarna (1999b) Kohti asiakaslähtöisyyttä ja kilpailukykyä. Sisäinen yrittäjyys kunnallisen yksikön muutoksessa. Turun kauppakorkeakoulun julkaisuja sarja A-5:1999.

HUUSKONEN, Visa (1992) Yrittäjäksi ryhtyminen. Teoreettinen viitekehys ja sen koettelu. Turun kauppakorkeakoulun julkaisuja sarja A-2:1992.

KANTER, Rosabeth Moss (1983) The Change Masters. Corporate Entrepreneurs at Work. Simon and Schuster: New York.

KOIRANEN, Matti - Pohjansaari, Tuija (1994) Sisäinen yrittäjyys. Innovatiivisuuden, laadun ja tuottavuuden perusta. Konetuumat Oy: Tampere.

KURATKO, Donald F. - Montagno, Ray V. - Hornsby, Jeffrey S. (1990) Developing an Intrapreneurial Assessment Instrument for an Effective Corporate Entrepreneurial Environment. Strategic Management Journal, Vol. 11, Summer Special Issue, 49-58.
KYRÖ, Paula (1997) Yrittäjyyden muodot ja tehtävä ajan murroksessa. Jyväskylä Studies in Computer Science, Economics and Statistics 38. Jyväskylä University Printing House: Lievestuore.

LANDSTRÖM, Hans - Huse, Morten (1996) Trends in European Entrepreneurship and Small-Business Research. A Comparison between Europe and the U.S. SIRE Working Paper 1996:3.

MacMILlAN, Ian C. (1986) Progress in Research on Corporate Venturing. Teoksessa The Art and Science of Entrepreneurship (toim. Donald L. Sexton ja Raymon W. Smilor). Ballinger: Cambridge, 241-263.

MILLER, Danny (1983) The Correlates of Entrepreneurship in Three Types of Firms. Management Science, Vol. 29, No. 7, 770-791.

MÖTTÖNEN, Sakari (1998) Tulosjohtaminen ja valta poliittisten päätöksentekijöiden ja viranhaltijoiden välisessä suhteessa. Hallinnon tutkimus, Vol. 18, No. 1, 63-65

PEARCE, John A. - Robertson Kramer, Tracy - Robbins, D. Keith (1997) Effects of Managers' Entrepreneurial Behavior on Subordinates, Journal of Business Venturing, Vol. 12, No. 2, 147-160.

PINCHOT, Gifford III (1985) Intrapreneuring: Why You Don't Have to Leave the Corporation to become an Entrepreneur. Harper \& Row Publishers, Inc.: New York.

STEYAERT, Chris (1995) Perpetuating Entrepreneurship through Dialogue - A Social Constructionist View. Faculty of Psychology and Educational Sciences. Department of Work and Organizational Psychology. Katholieke Universiteit Leuven.

van de VEN, Andrew H. (1993) The Development of an Infrastructure for Entrepreneurship. Journal of Business Venturing, Vol. 8, No. 3, 211-230.

WILSON, Alan M. (1997) The Nature of Corporate Culture within a Service Delivery Environment. International Journal of Service Industry Management, Vol. 8, No. 1, 87-102.

ZAHRA, Shaker A. (1991) Predictors and Financial Outcomes of Corporate Entrepreneurship: An Explanatory Study. Journal of Business Venturing, Vol. 6, No. 4, 259-285.

\section{Viitteet}

1 Strategic Management Journal 1990, Vol. 11, Summer Special Issue

2 Guth ja Ginsberg (1990) typistävät sisäisen yrittäjyyden tutkimuskentän ja sisäiseen yrittäjyyteen vaikuttavat tekijät neljään osa-alueeseen: 1) ympäristö 2) strategiset johtajat 3) organisaation toimintatavat ja rakenne sekä 4) organisaation menestyminen.

3 Miller (1983) jakaa yrittäjyyteen vaikuttavat tekijät seuraavasti: 1) johtajan persoonallisuus 2) ympäristöön ja kulttuuriin liittyvät tekijät sekä 3) päätöksentekomekanismi ja strategia.

4 Kuratko et al. (1990) jakavat yrittäjyyteen vaikuttavat tekijät seuraavasti: 1) palkkiojärjestelmä 2) johdon halu helpottaa yrittäjyysprosessia 3) resurssit (mukaan lukien aika) 4) organisaatiorakenne sekä 5) riskin ottaminen (sekä johdon että työntekijöiden).

Artikkeli saapui 5.1. ja sen hyväksyttiin julkaistavaksi 25.4. 